\title{
Seasonal Effect of Vitamin C, Electrolyte and Jaggery Supplementation on Body Weight of Goats Transported at Different Flocking Density
}

\author{
Deepanshu Gupta ${ }^{1}$, Manju Ashutosh ${ }^{1}$, Gayatri Kashyap ${ }^{2 *}$, Meeti Punetha ${ }^{1}$, \\ Ashutosh ${ }^{1}$, Bharti Patel ${ }^{1}$, Irshad Para ${ }^{1}$ and Maneesh Ahirwar ${ }^{3}$ \\ ${ }^{1}$ Animal Physiology division, National Dairy Research Institute, \\ Karnal-132001, Haryana, India \\ ${ }^{2}$ Division of Pathology, Indian Veterinary Research Institute, Bareilly-243122, UP, India \\ ${ }^{3}$ LPM division, National Dairy Research Institute, Karnal-132001, Haryana, India \\ *Corresponding author
}

\section{A B S T R A C T}

Present work was conducted during two seasons (winter and hot-humid) to investigate seasonal effect of transportation of goats at different flocking densities on physiological parameters in goats (Alpine $\mathrm{x}$ Beetal) supplemented with Vitamin C, Vitamin C + Electrolyte and Jaggery. Goats were of 10-12 months of age from LRC, NDRI Karnal. During the journey all the animals were kept off-feed and deprived of water. The animals

\section{Keywords}

Body weight,

Electrolyte, Jaggery,

Transportation stress and Vitamin C

Article Info

Accepted:

16 March 2018

Available Online:

10 April 2018 were divided into four groups. Group I, II and III consisted of 25 goats each that were further divided into groups of high (15) and low (10) flocking density. 3 days before start of experiment, group I goats were fed Vitamin C, group II goats were fed Vitamin C and Electrolyte and group III goats were fed jaggery only. These goats were subjected to continuous 8 hours transport in a tractor trailer measuring $12 \mathrm{ft} \times 6 \mathrm{ft} .=7.2 \mathrm{~m}^{2}$ at an average speed of $25 \mathrm{~km}$ per hour for 3 days. Group IV goats served as control consisting of 10 animals and were kept in shed off fed up to $8 \mathrm{~h}$ on the day of transportation. Body weights were recorded before and after transportation. Body weight loss was more prominent in high flocking density goats as compared to low flocking goats in all three groups in both seasons. The lowest $(\mathrm{P}<0.05)$ values of body weights were recorded just after unloading in all groups, at low as well as high flocking densities in both seasons which then increased gradually after $6 \mathrm{~h}$ of rest and feeding and reached to basal values after 24 hours after unloading. High flocking density was more stressful than low flocking density so animals should provide optimum floor space while transportation. Supplementation of Vitamin C, Vitamin C + Electrolyte and Jaggery aided in reducing transportation stress individually but Vitamin $\mathrm{C}+$ Electrolyte combination proved more beneficial in alleviating transportation stress in goats.

\section{Introduction}

Studies regarding road transportation of livestock have revealed that the animals are exposed to numerous stressors and the responses of the animal to them are complex, non-specific and often detrimental to their health and productivity (Minka and Ayo, 2009). Besides feed and water deprivation, livestock transport involves a complex set of 
actions including handling, loading and unloading, unfamiliar environments etc. It may cause injury, reduced performance, increased morbidity and mortality rate and consequently substantial economic losses due to loss of live weight and poor meat quality (Knowles et al., 1999a; Fazio and Ferlazzo, 2003 and Minka and Ayo, 2007a).

Transportation stress in animals has been scientifically established to produce shrinkage in body weight (Kannan et al., 2002). Transportation involving extended periods without food and water resulted into an initial loss of live weight (approx. $7 \%$ in ruminants and $4 \%$ in pigs) during the first 18-24 hrs of transportation (Knowles and Warriss, 2007).

Supplementation of Vitamin C, electrolyte aided in reducing transportation stress individually, with variable effects on stress response parameters and their combination synergistically proved promising in alleviating transportation stress in goats (Minka and Ayo, 2013). The application of oral electrolyte therapy, especially if similar in constituents to interstitial fluid, seems to attenuate the changes, resulting in improving both live and carcass weights up to several percent in treated animals as well as a reduction in meat quality degradation (reduced dark cutting). These studies suggest that the use of electrolyte therapy may be an effective means of reducing stress in transported cattle (Schaefer et al., 1997)

The majority of the studies conducted on the transportation of goats have been done in temperate regions of the world (Rajion et al., 2001) and not in tropical conditions. Measures aimed at alleviating road transportation stress in goats are still limited (Galipalli et al., 2004 and Minka and Ayo, 2007b). The aim of present study was to investigate the synergistic effect of treatment with ascorbic acid, electrolytes and jiggery on body weights of goats at different flocking densities, in hot humid and winter conditions.

\section{Materials and Methods}

Animal experimentation was performed in compliance with regulations set by the Livestock Research Centre, NDRI and approved by the Institutional Animal Ethics Committee (IAEC). Cross bred goats (Alpine $\mathrm{x}$ Beetle) of 10-12 months of age were selected for experiment from LRC, NDRI Karnal, which is situated at an altitude of 250 meters above mean sea level and at $29^{\circ} 42^{\prime} \mathrm{N}$ latitude and $77^{\circ} 02^{\prime}$ E longitudes. The maximum temperature recorded goes up to $45^{\circ}$ $\mathrm{C}$ in summer and minimum temperature $3.5^{\circ}$ to $4^{\circ} \mathrm{C}$ in winter. The average rainfall is about $700 \mathrm{~mm}$. The whole experiment was conducted in two seasons: during hot humid season (September-October) and during winter season (December-January).

The animals were divided into four groups: Group I, II and III consisted of 25 goats each, that were further divided into groups of high (15) and low (10) flocking density. These goats were subjected to continuous 8 hours transport in a tractor trailer measuring $12 \mathrm{ft} x$ 6 feet $=7.2 \mathrm{~m}^{2}$ at a minimum speed of $25 \mathrm{~km}$ per hour for 3 days. During the journey all the animals were kept off-feed and deprived of water. The trailer was divided into two parts of $3 \mathrm{~m}^{2}$ each. Floor area for transportation was calculated and $0.20 \mathrm{~m}^{2}$ per goat/sheep weighing up to $20-25 \mathrm{~kg}$ of body weight, were classified as low flocking density. Similarly, for high density group the floor area was calculated and $0.14 \mathrm{mt}^{2}$ per goat/sheep weighing up to $20-25 \mathrm{~kg}$ of body weight was considered. In group III, the body weights of animals taken under study varied between 16$20 \mathrm{~kg}$. Further group I goats were fed vitamin $\mathrm{C}$, group II goats were fed vitamin $\mathrm{C}$ and electrolyte and group III goats were supplemented with jaggery three days before 
the start of experiment. Group IV: This group consisted of 10 growing goats that were maintained under goat section of the LRC, NDRI, Karnal receiving all normal management inputs as practiced at goat unit of the institute. This group was never transported and kept without feed, water and fodder in an enclosure/shed till the completion of 8 hours transportation activity/process for other goat groups. All the goats were maintained under goat section of the LRC, NDRI, Karnal received all normal management inputs as practiced at goat unit of the institute.

Group I was fed vitamin C at a dose of 180 $\mathrm{mg} / \mathrm{kg}$.bwt/day/animal orally. Group II was fed with vitamin $\mathrm{C}+$ electrolyte (180 $\mathrm{mg} / \mathrm{kg}$. bwt/day/animal of vitamin $\mathrm{C}+7 \mathrm{~g} /$ animal / day Electral powder) and group III was fed jaggery@dose of 200 g/animal/day orally with small amount of concentrate

The vehicle used for transportation was tractor trailer covered on all sides with wire mesh. The tractor was driven by three licensed and trained drivers alternately for 2.5 hours to 3 hours on the day of experiment, thus accounting for total 8 hours duration of continuous transportation. The average speed of vehicle was maintained on an average of 25 $\mathrm{km}$ per hour. The average floor area on the trailer for transportation of experimental goats was decided on the basis of studies carried out and available reports/ literature (The Australian Standards and Guidelines for the Welfare of Animals - Livestock Transport version 1.126 September 2011; Ministry Of Environment and Forests, 2009) in the country and outside country. The trailer measuring 12 $\mathrm{ft} \times 6 \mathrm{ft}=7.2 \mathrm{~m}^{2}$ was divided into two parts of $3 \mathrm{~m}^{2}$ each. The duration of animal transport for each group was 3 days in each season. Body weights of goats were measured with the help of electronic weighing balance early in the morning before feeding on each day of sampling and expressed in $\mathrm{kg}$.
Data analysis was carried out using SAS 9 software licensed to NDRI. Mean values at different sampling times were compared with respective basal mean values of each group using one way ANOVA with posttest as Dunnets multiple comparison.

\section{Results and Discussion}

Meteorological data in the month of Sep-Oct and Dec-Jan THI was 77.14 and 58.74 respectively. This suggests a hot humid $(\mathrm{HH})$ and winter seasons in Karnal, India. The average $( \pm \mathrm{SE})$ values of body weight $(\mathrm{Kg})$ in groups (group I, group II, group III and group IV) of goats at low and high flocking density, during winter and hot-humid seasons have been presented in table 1 and graphically depicted in figure 1 . The analysis of variance for body weight has been presented in table 2 .

During winter season body weight of group I goats was significantly $(\mathrm{P}<0.05)$ lower at unloading $(22.78 \pm 0.16)$ with body weight shrinkage of $3.87 \%$ as compared to normal basal body weight $(23.69 \pm 0.14)$ in low density goats before transportation, but 24 hours after transportation body weight returned to normal basal level whereas in high flocking density the body weight shrinkage was $5.79 \%$ after unloading. Similarly the body weight shrinkage were also reported in hot humid season in low as well as in high flocking density goats up to $4.85 \%$ and $6.15 \%$ respectively, after unloading. In group II, during winter season the body weight shrinkage was $2.82 \%$ for low flocking density and $3.41 \%$ in high flocking density goats after transportation. The body weight shrinkage in high flocking density goats was $4.69 \%$ in hot humid season whereas low flocking density goats showed only $2.54 \%$ shrinkage which was minimum among all the groups. The maximum body weight shrinkage was reported in group III as compared to group I and II goats. 
Table.1 Average values of Body weight $(\mathrm{Kg})$ in goats transported at different flocking densities during winter and hot humid seasons

\begin{tabular}{|c|c|c|c|c|}
\hline \multirow{2}{*}{$\begin{array}{l}\text { Transportation } \\
\text { Groups }\end{array}$} & \multicolumn{2}{|l|}{ WINTER } & \multicolumn{2}{|l|}{ HOT HUMID } \\
\hline & $\begin{array}{l}\text { Low Flocking } \\
\text { Density }\end{array}$ & $\begin{array}{l}\text { High Flocking } \\
\text { Density }\end{array}$ & $\begin{array}{l}\text { Low Flocking } \\
\text { Density }\end{array}$ & $\begin{array}{l}\text { High Flocking } \\
\text { Density }\end{array}$ \\
\hline \multicolumn{5}{|c|}{ Vitamin C (Group I) } \\
\hline Before Loading & $23.69 \pm 0.14^{\text {hy }}$ & $23.50 \pm 0.11^{\mathrm{ex}}$ & $21.78 \pm 0.24^{\mathrm{ew}}$ & $21.67 \pm 0.21^{\mathrm{fw}}$ \\
\hline After Unloading & $22.78 \pm 0.16^{\mathrm{ez}}$ & $22.14 \pm 0.11^{\mathrm{dy}}$ & $20.72 \pm 0.20^{\mathrm{cx}}$ & $20.33 \pm 0.23^{\mathrm{ew}}$ \\
\hline 6h Post & $22.58 \pm 0.13^{\mathrm{ez}}$ & $22.00 \pm 0.10^{\mathrm{dy}}$ & $20.50 \pm 0.16^{\mathrm{cx}}$ & $20.00 \pm 0.17^{\mathrm{dw}}$ \\
\hline 12h Post & $22.83 \pm 0.13^{\mathrm{fz}}$ & $22.25 \pm 0.09^{\mathrm{dy}}$ & $20.83 \pm 0.19^{\mathrm{cx}}$ & $20.42 \pm 0.16^{\mathrm{ew}}$ \\
\hline 24h Post & $23.17 \pm 0.09^{\mathrm{gz}}$ & $22.75 \pm 0.09^{\mathrm{ey}}$ & $21.33 \pm 0.19^{\mathrm{dx}}$ & $20.75 \pm 0.18^{\mathrm{ew}}$ \\
\hline 48h Post & $23.67 \pm 0.17^{\mathrm{hz}}$ & $23.42 \pm 0.11^{\mathrm{ey}}$ & $21.75 \pm 0.21^{\mathrm{ex}}$ & $21.08 \pm 0.16^{\mathrm{ew}}$ \\
\hline \multicolumn{5}{|c|}{ Vitamin C and Electrolyte Mixture (Group II) } \\
\hline Before Loading & $23.64 \pm 0.12^{\mathrm{hx}}$ & $23.61 \pm 0.13^{\mathrm{dx}}$ & $21.86 \pm 0.25^{\mathrm{ew}}$ & $21.92 \pm 0.20^{\mathrm{fw}}$ \\
\hline After Unloading & $22.97 \pm 0.13^{\mathrm{gz}}$ & $22.81 \pm 0.13^{\mathrm{dx}}$ & $21.31 \pm 0.24^{\mathrm{dx}}$ & $20.89 \pm 0.22^{\mathrm{ew}}$ \\
\hline 6h Post & $22.83 \pm 0.15^{\mathrm{fz}}$ & $22.67 \pm 0.13^{\text {dy }}$ & $21.00 \pm 0.22^{\mathrm{dx}}$ & $20.42 \pm 0.25^{\mathrm{ew}}$ \\
\hline 12h Post & $23.00 \pm 0.14^{\mathrm{gy}}$ & $23.00 \pm 0.12^{\text {ey }}$ & $21.33 \pm 0.23^{\mathrm{dx}}$ & $20.75 \pm 0.24^{\mathrm{ew}}$ \\
\hline 24h Post & $23.33 \pm 0.11^{\mathrm{hz}}$ & $23.25 \pm 0.12^{\mathrm{ey}}$ & $21.75 \pm 0.21^{\mathrm{ex}}$ & $21.25 \pm 0.25^{\mathrm{ew}}$ \\
\hline 48h Post & $23.83 \pm 0.11^{\text {hy }}$ & $23.75 \pm 0.14^{\mathrm{ey}}$ & $22.25 \pm 0.18^{\mathrm{dx}}$ & $21.58 \pm 0.20^{\mathrm{fw}}$ \\
\hline \multicolumn{5}{|c|}{ Jaggery Solution (Group III) } \\
\hline Before Loading & $19.45 \pm 0.46^{\mathrm{cy}}$ & $19.48 \pm 0.46^{\text {by }}$ & $17.78 \pm 0.50^{\mathrm{bx}}$ & $17.09 \pm 0.42^{\mathrm{cw}}$ \\
\hline After Unloading & $17.99 \pm 0.43^{\mathrm{az}}$ & $17.38 \pm 0.30^{\text {ay }}$ & $16.32 \pm 0.44^{\mathrm{ax}}$ & $15.43 \pm 0.35^{\mathrm{aw}}$ \\
\hline 6h Post & $18.45 \pm 0.41^{\text {by }}$ & $19.43 \pm 0.46^{\mathrm{bz}}$ & $16.58 \pm 0.40^{\mathrm{ax}}$ & $16.11 \pm 0.45^{\mathrm{bw}}$ \\
\hline 12h Post & $19.37 \pm 0.45^{\mathrm{cx}}$ & $19.45 \pm 0.48^{b x}$ & $17.05 \pm 0.45^{\mathrm{bw}}$ & $17.00 \pm 0.42^{\mathrm{cw}}$ \\
\hline 24h Post & $19.52 \pm 0.46^{\mathrm{cx}}$ & $19.47 \pm 0.45^{\text {by }}$ & $17.09 \pm 0.42^{b w}$ & $17.17 \pm 0.43^{\mathrm{cw}}$ \\
\hline 48h Post & $19.45 \pm 0.47^{\mathrm{cy}}$ & $19.45 \pm 0.46^{\text {by }}$ & $17.74 \pm 0.50^{\mathrm{cx}}$ & $17.12 \pm 0.42^{\mathrm{cw}}$ \\
\hline \multicolumn{5}{|l|}{ Control (Group IV) } \\
\hline Before Loading & $21.23 \pm 0.88^{\mathrm{az}}$ & $21.43 \pm 0.88^{\mathrm{bz}}$ & $20.86 \pm 0.88^{\text {aw }}$ & $19.86 \pm 0.78^{\mathrm{cx}}$ \\
\hline After Unloading & $20.74 \pm 0.90^{\mathrm{az}}$ & $20.94 \pm 0.90^{\mathrm{bz}}$ & $20.41 \pm 0.87^{\mathrm{bw}}$ & $18.91 \pm 0.75^{\mathrm{cx}}$ \\
\hline
\end{tabular}

Between rows a, b, c and d and between columns $w, x, y$ and $\mathrm{z}$ differed significantly $(\mathrm{P}<0.05)$

Table.2 Analysis of variance for body weight in transported goats

\begin{tabular}{|l|l|l|}
\hline Source of variation & Df & Mean Sum Squares \\
\hline Between Seasons & $\mathbf{1}$ & $1172.55^{* *}$ \\
\hline Between Densities & $\mathbf{3}$ & $405.55^{* *}$ \\
\hline Between Treatments & $\mathbf{1 7}$ & $294.37 * *$ \\
\hline Season x Treatments & $\mathbf{1 7}$ & $5.36 *$ \\
\hline Densities x treatments & $\mathbf{5 1}$ & $2.69 *$ \\
\hline With in & $\mathbf{1 2 0 6}$ & 2.26 \\
\hline Total & $\mathbf{1 2 9 5}$ & - \\
\hline
\end{tabular}

$\mathrm{P}<0.05^{*} \mathrm{P}<0.01^{* *}$ 
Electrolyte which is based on W.H.O formulae manufactured by FDC limited trade name Electral is used which supplies electrolytes in the following concentrations:

\begin{tabular}{|l|c|}
\hline Electrolytes & mOsmol / Litre \\
\hline Sodium & 75 \\
\hline Potassium & 20 \\
\hline Chloride & 65 \\
\hline Citrate & 10 \\
\hline Dextrose & 75 \\
\hline Total Osmolarity & 245 \\
\hline
\end{tabular}

Fig.1 Average values of Body weight $(\mathrm{Kg})$ in goats transported at different flocking densities during winter and hot humid seasons
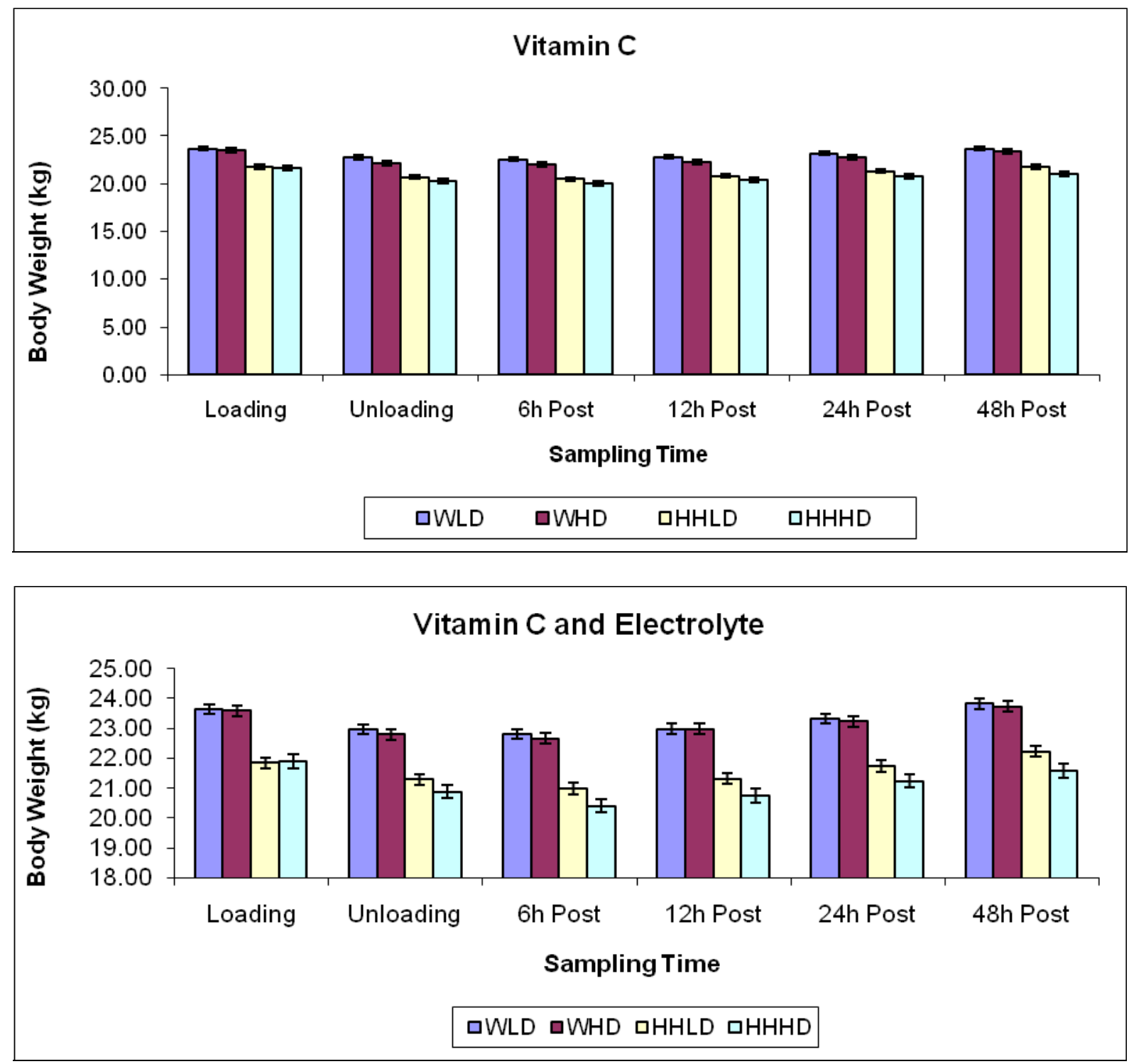


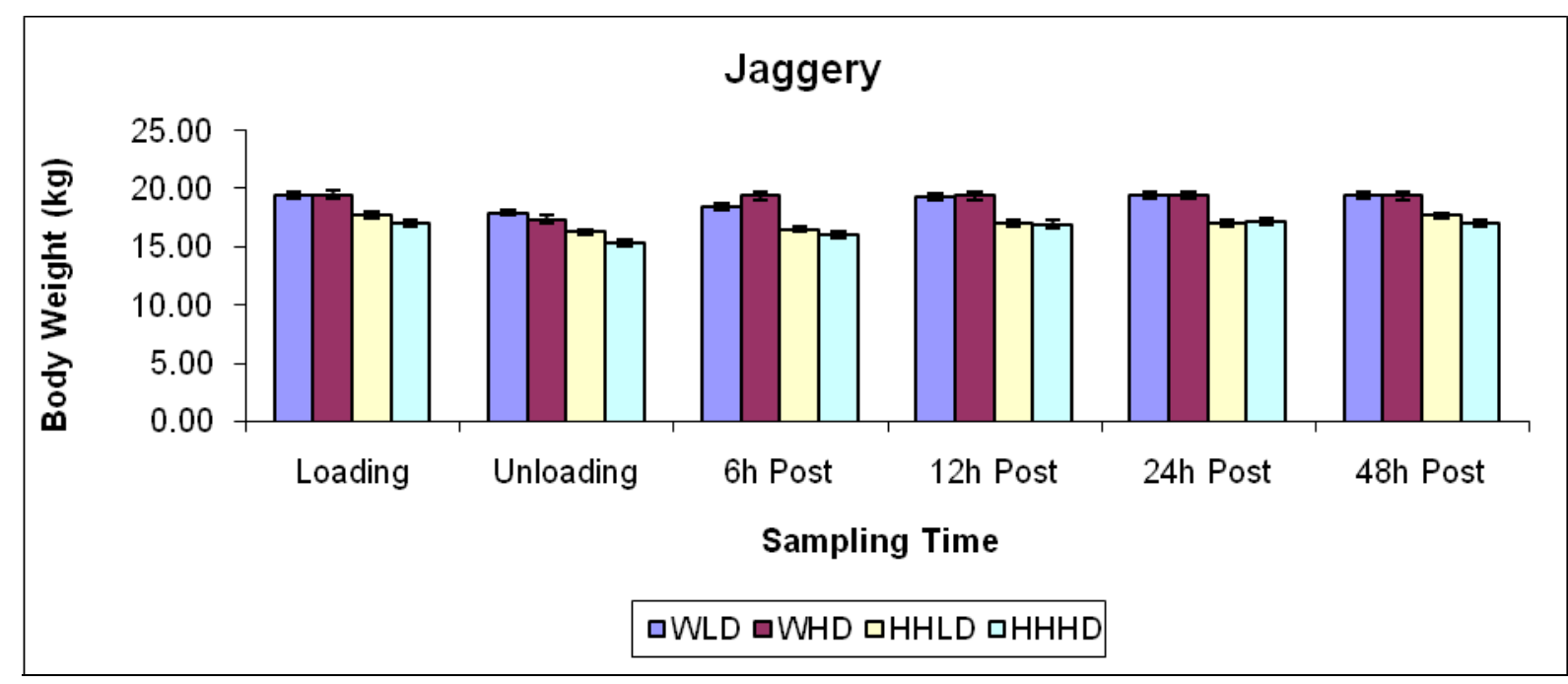

The percent body weight shrinkage in winter and hot humid seasons were $7.48 \%, 10.81 \%$, $8.19 \%$ and $9.75 \%$ in low and high flocking density goats respectively, at unloading compared to basal values with significant $(\mathrm{P}<0.05)$ differences. In group IV (control) during winter and summer seasons no significant variation was reported in body weights during the study. Analysis of Variance for body weight indicated that there was a significant difference $(\mathrm{P}<0.05)$ between seasons, between density and between groups. There was a significant $(\mathrm{P}<0.05)$ interaction between season, density and groups.

In group I and group II the body weight were either not affected by transportation or regained immediately post transportation, indicating the role of vitamin $\mathrm{C}$ and electrolytes in preventing body weight shrinkage due to transportation in goats. The live weight shrinkage in transported goats can be partly contributed to dehydration as represented by increased PCV of transported goats and can be also contributed to increased protein catabolism due to increased cortisol. The insignificant live body weight shrinkage in vitamin $\mathrm{C}$ and electrolyte group can be due to less muscle catabolism. The mechanism by which ascorbic acid (Vitamin C) reduced live weight loss during transportation may be as a result of the inhibitory role of ascorbic acid on cortisol, the chief hormone of stress, which induces diuresis and increases elimination of the gut content (Balz, 2003; Powers and Jackson, 2008).

Knowles and Warriss (2007) reported that transportation involving extended periods without food and water results into an initial loss of live weight (approx. 7\% in ruminants and $4 \%$ in pigs) during the first $18-24 \mathrm{hrs}$ of transportation. Other workers have also reported that transporting animals for a long distance is found to cause a loss in live weight or carcass weight (Minka and Ayo, 2007b; 2008; Minka et al., 2009; Ritter et al., 2008). Warriss (1993) reported that animal loss weight when they are subjected to greater energy demand such as those needed to maintain thermoregulation in transport. Alamer and Al-Hozab (2004) found that variations in body weight loss of sheep during winter, spring and summer seasons, was mostly contributed to body water loss as related to differences in environmental temperature. The greatest body loss that was observed during summer was in association with respiratory and cutaneous water losses.

Goats transported for $12 \mathrm{hrs}$ over a distance of about $350 \mathrm{Km}$ revealed significant decrease in the live body weight than their preload weight. After transportation an average 5.77, 
2.39 and 4.80 per cent shrinkage of the body weight was observed in group II (positive control), III (given Restobal liquid@20 $\mathrm{ml} / \mathrm{animal}$ ) and IV (given Stresomix premix@5gm/day/animal with gur for 10 days) respectively than their pre-transport body weight. Positive control group administered no treatment exhibited significantly $(\mathrm{P}<0.01)$ higher shrinkage in body weight than the polyherbal formulation supplemented treatment groups. However, among the treatments, restobal administered group showed significantly $(\mathrm{P}<0.01)$ lower shrinkage than the Stresomix premix administered group (Ambore et al., 2009). Similarly (Minka and Ayo, 2007b), reported that 8 hours transportation of Red Sokoto goats (RSG) treated with ascorbic acid (AA) lost only $1.04 \%$ compared to control goats which lost $11.9 \%$ of their initial live weight after transportation. Transportation of goats upto 8 hours during hot humid and winter seasons induced stress as is reflected by decreased values of body weight just after unloading. Supplementation of vitamin $\mathrm{C}+$ electrolyte showed lesser deviations from the normal values as compared to other groups, indicating that a combination of vitamin $\mathrm{C}$ and electrolyte was more beneficial in reducing the transportation effect.

\section{Acknowledgement}

The authors are thankful to Head, Animal Physiology Division and Director, NDRl, Karnal for providing necessary facilities for carrying out this study.

\section{References}

Alamer, M., and Al-Hozab, A. 2004. Effect of water deprivation and season on feed intake, body weight and thermoregulation in Awassi and Najdi sheep breeds in Saudi Arabia. J. Arid. Environ. 59: 71-84.
Ambore, B., Ravikanth, K., Maini, S. and Rekhe, D.S. 2009. Haematological Profile and Growth Performance of Goats under Transportation Stress. Veterinary World, 2 (5): 195-198.

Balz, F. 2003. Vitamin C intake. Nutr. Dis. 14: 1-8.

Das, T.K. and Teng, B.S. 2000. A resourcebased theory of strategic alliances. Journal of management, 26(1): 31-61.

Fazio, E. and Ferlazzo, A. 2003. Evaluation of stress during transport. Vet. Res. Commun., 27: 519-524

Galipalli, S., Gadiyaram, K.M., Kouakou, B., Terril, T.H. and Kannan, G. 2004. Physiological response of preslughter transportation stress in Tascosupplemented goats. South African Journal of Animal Science, 34: 198200.

Kannan, G., Terril, T.H., Kouokou, B., Gelaye, S. and Amoah, E.A. 2002. Simulated preslaughter holding and isolation effects on stress responses and live mass shrinkage in meat goats. Journal of meat science, 80: 1771-1780.

Knowles, T.G., Brown, S.N., Edwards, J.E., Philips, A.J. and Warriss, P.D. 1999a. Effect on young calves of a one-hour feeding stop during a 19-hour road journey. Vet. Rec. 144: 687-692.

Knowles, T.G., Warriss, P.D. 2007. Stress physiology of animals during transport, In: Grandin, T. (Ed.) Livestock Handling and Transport $3^{\text {rd }}$ edn, CAB International Walling ford, Oxon: 312328.

Minka, N. S. and Ayo, J. O. 2007. Physiological responses of transported goats treated with ascorbic acid during the hot-dry season. Animal Science Journal 78(2): $164-172$.

Minka, N. S. and Ayo, J. O. 2009. Physiological responses of food animals 
to road transportation stress. Afri. J. Biotech. 8 (25): 7415-7427

Minka, N.S and Ayo, J.O. 2013. Physiological and behavioral responses of goats to 12-hour road transportation, lairage and grazing periods, and the modulatory role of ascorbic acid. Journal of Veterinary Behavior, 8: 349356.

Minka, N.S and Ayo, J.O. 2007a. Effects of loading behaviour and road transportation stress on traumatic injuries in cattle transported by road during hot- dry season. Livestock Science, 107: 91-95.

Minka, N.S. and Ayo, J.O. 2007b. Physiological responses of transported goats treated with ascorbic acid during the hot dry season. Animal Science Journal, 78: 162-172.

Minka, N.S. and Ayo, J.O. 2008.Haematology and behaviour of pullets transported by road and administered with ascorbic acid during the hot dry season. Research in Veterinary Science. 85 (2): 389-393

Minka, N.S., Ayo, J.O., Sackey, A.K.B. and Adelaiye, A.B. 2009. Assessment and scoring of stresses imposed on goats during handling, loading, road transportation and unloading and the effect of pretreatment with ascorbic acid. Life Sci. 125: 275-282.

Notification, Ministry of Environment and Forests. New Delhi, the $22^{\text {nd }}$ September, 2009

Powers, S.K. and Jackson, M.J. 2008. Exercise-induced oxidative stress: cellular mechanisms and impact on muscle force production. Physiol. Rev. 88: 1243-1276.

Rajion, M. A., Soat, I.M, Zulkifli, I. and Goh, Y.M. 2001. The effects of road transport on some physiological stress measures in goats. Asian- Australian Journal of Animal Science, 9: 12501262.

Ritter, M.J., Ellis, M., Bowman, R., Brinkmann, J., Curtis, S.E., DeDecker, J.M., Mendoza, O., Murphy, C.M., Orellana, D.G., Peterson, B.A., Rojo, A., Schlipf, J.M. and Wolter, B.F. 2008. Effects of season and distance moved during loading on transport losses of market-weight pigs in two commercially available types of trailer. J. Anim. Sci. 86: 3137-3145.

Schaefer, A.L., Jones, S.D.M. and Stanley, R.W. 1997. The use of electrolyte solutions for reducing transport stress. J. Anim. Sci. 75: 258-265.

Tarrant, V. and Grandin, T. 2000. Cattle transport. In: Grandin, T. (ed.), Livestock Handling and Transport: 151-174.

The Australian Standards and Guidelines for the Welfare of Animals - Livestock Transport version 1.126 September 2011.

Warriss, P.D., Kestin, S.C., Brown, S.N., Knowles, T.G., Wilkins, L.J., Edwards, J.E., Austin, S.D. and Nicol, C.J. 1993. The depletion of glycogen stores and indices of dehydration in transported broilers. British

Veterinary Journal, 149(4): 391-398.

\section{How to cite this article:}

Deepanshu Gupta, Manju Ashutosh, Gayatri Kashyap, Meeti Punetha, Ashutosh, Bharti Patel, Irshad Para and Maneesh Ahirwar. 2018. Seasonal Effect of Vitamin C, Electrolyte and Jaggery Supplementation on Body Weight of Goats Transported at Different Flocking Density. Int.J.Curr.Microbiol.App.Sci. 7(04): 1761-1768. doi: https://doi.org/10.20546/ijcmas.2018.704.200 